Chikwendu Ibebunjo DVM PhD, *

Dayle Eshelby BA, ${ }^{\dagger}$

François Donati PhD MD FRCPC,

Gordon S. Fox MD FRCPC, *

Jean I. Tchervenkov MDCM $^{\dagger}$

\section{Tacrine does not alter the potency of succinylcholine in the rat*}

Purpose: Tacrine is a cholinesterase inhibitor used to manage Alzheimer's dementia. Given iv, it prolongs succinylcholine blockade in humans but the effects of chronic oral tacrine are not known.

Methods: Groups of adult rats were given $2.5 \mathrm{mg} \cdot \mathrm{kg}^{-1}$ tacrine (chronic groups) or I m/ saline (control) twice daily by gavage for one, two, four or eight weeks. An additional (acute) group received $2.5 \mathrm{mg} \cdot \mathrm{kg}^{-1}$ tacrine in. Twelve to $18 \mathrm{hr}$ after the last gavage of tacrine or saline, and $\sim 20 \mathrm{~min}$ after iv tacrine, cumulative dose-response curves of succinylcholine were determined in the tibialis and soleus muscles in anaesthetized, ventilated rats during monitoring of evoked twitch response to indirect (nerve) train-of-four stimulation.

Results: The $\mathrm{ED}_{50}$ and $\mathrm{ED}_{95}$ of succinylcholine in control rats were (mean \pm SD) $204 \pm 41$ and $382 \pm 96$ $\mu \mathrm{g} \cdot \mathrm{kg}^{-1}$, respectively, in the tibialis muscle, and $280 \pm 52$ and $629 \pm 168 \mu \mathrm{g} \cdot \mathrm{kg}^{-1}$ in the soleus muscle $(P<0.05$ between muscles). In the acute and chronic tacrine groups, the mean $\mathrm{ED}_{50}$ and $\mathrm{ED}_{95}$ ranged from 166-197 and $277-396 \mu \mathrm{g}^{\circ} \mathrm{kg}^{-1}$, respectively, in the tibialis muscle, and $248-333$ and $546-667 \mu \mathrm{g}^{-\mathrm{kg}^{-1}}$, in the soleus muscle. Dose responses did not differ among acute and chronic tacrine groups and the control group.

Conclusion: Chronic oral tacrine does not alter muscle response to succinylcholine in the rat. This may not apply to Alzheimer patients receiving chronic tacrine since the interaction between acute tacrine and succinylcholine in the rat differs from that in humans.

Objectif : La tacrine est un inhibiteur de la cholinestérase utilisé dans le traitement de la maladie d'Alzheimer. Par la voie intraveineuse, la tacrine prolonge le bloc provoqué par la succinyicholine chez l'humain mais on ne connait pas ses effets en administration orale prolongee.

Méthodes : Deux groupes de rats ont reçu $2,5 \mathrm{mg} \cdot \mathrm{kg}^{-1}$ de tacrine (groupe prolongé) ou $1 \mathrm{ml}$ de sol. phys. (le groupe controle) par gavage pendant une, deux, quatre ou huit semaines. Un troisième groupe (le groupe ponctuel) a reçu $2,5 \mathrm{mg} \cdot \mathrm{kg}^{-1}$ de tacrine iv. De douze à dix-huit $\mathrm{h}$ après le dernier gavage de tacrine ou de sol. phys. et $\sim 20$ min après la tacrine $i$, des courbes dose/effet cumulatives spécifiques à la succinylcholine ont été établies pour les muscles tibial et soléaire chez les rats anesthésiés et ventilés pendant le monitorage des réponses évoquées au twitch par stimulation indirecte (nerveuse) au train-de-quatre.

Résultats : $L^{\prime} E D_{50}$ et l'ED de la succinylcholine chez les rats contrôles étaient (moyenne \pm É) respectivement $204 \pm 41$ et $382 \pm 96 \mu \mathrm{g}^{\circ} \mathrm{kg}^{-1}$ au muscle tibial, et $280 \pm 52$ et $629 \pm 168 \mu \mathrm{g}^{\circ} \mathrm{kg}^{-1}$ au muscle soléaire $\left(P<0,05\right.$ entre ces muscles). Chez les groupes tacrine ponctuel et prolongé. I'ED ${ }_{50}$ et l'ED 95 se situaient respectivement entre $166 \mathrm{et} 197 \mu \mathrm{\mu g} \cdot \mathrm{kg}^{-1}$ et entre 277 et $396 \mu \mathrm{g}^{\prime} \mathrm{kg}^{-1}$ au muscle tibial et entre $248 \mathrm{et} 33 \mu \mathrm{gg} \cdot \mathrm{kg}^{-1}$ et entre $546 \mathrm{et} 667 \mu \mathrm{g}^{\prime} \mathrm{kg}^{-1}$ au muscle soléaire. La relation dose à effet était identique entre les deux groupes tacrine et le groupe controle.

Conclusion : L'administration orale prolongée de la tacrine ne modifie pas la réponse musculaire à la succinylcholine chez le rat. Comme l'interaction entre la tacrine administré ponctuellement et la succinylcholine chez le rat differe de celle de l'humain, ceci ne s'applique pas nécessairement au traitement prolongé de la maladie d'Azzheimer à la tacrine.

From the Departments of Anaesthesia* and Surgery, ${ }^{\dagger}$ Royal Victoria Hospital and McGill University, 687 Pine Avenue West, Montreal,

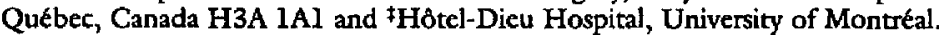

Address correspondence to: Dr. C. Ibebunjo, Shriners Burns Institute Research Center, Building 1400W, One Kendall Square, Cambridge, MA 02139, U.S.A.

*Preliminary data from this work were presented at the 52nd Annual Meeting of the Canadian Anaesthetists' Society, July 1995, Ottawa, Canada [Can J Anaesth 1995; 42: A75B]. Accepted for publication June $16,1997$. 
$\mathrm{T}$

ACRINE (1,2,3,4-tetrahydro-9-aminoacridine; Figure 1) is a reversible anticholinesterase that crosses the blood-brain barrier. It is in clinical use in the United States and France and under clinical trials in Canada and other countries for managing Alzheimer's dementia (AD) ${ }^{1-3}$ Although used in these patients for its central anticholinesterase effects, tacrine also inhibits cholinesterases in peripheral tissues, notably in plasma and at the neuromuscular junction. Its ability to inhibit plasma cholinesterase activity was exploited by anaesthetists to potentiate and prolong the action of succinylcholine, but this practice has been abandoned because of complications associated with development of phase II block. ${ }^{4}$ However, drug interactions involving tacrine may again be encountered because patients with $\mathrm{AD}$ may, while receiving chronic tacrine therapy, present for surgery requiring neuromuscular blockade. It is not known whether or how such chronic tacrine therapy might alter their response to succinylcholine.

The manufacturers of tacrine hydrochloride (Cogne $x^{\circledR}$, Parke-Davies, Morris Plains, NJ, USA) state that, as a cholinesterase inhibitor, it is likely to exaggerate succinylcholine-type muscle relaxants during anaesthesia, but they do not specify whether this refers to the effects after acute or chronic use. Intuitively, a simple potentiation would be expected after acute, but not chronic, tacrine treatment since the latter will cause chronic inhibition of both plasma cholinesterase and acetylcholinesterase at neuromuscular junctions, the latter causing progressive downregulation of postsynaptic acetylcholine receptors. ${ }^{5}$ Down-regulation of acetylcholine receptors would produce resistance to succinylcholine ${ }^{6}$ in contrast to the increased sensitivity due to inhibition of plasma cholinesterase. ${ }^{7}$ Hence, the effects of chronic tacrine therapy might not be a simple potentiation of the actions of succinylcholine but rather will depend on which of these two opposing effects dominates, which in turn will depend on the duration of tacrine therapy.

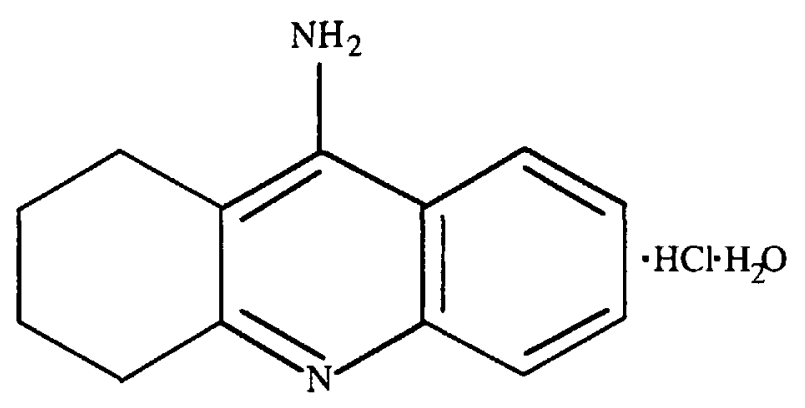

FIGURE I The structural formula of tacrine hydrochloride.
This study was designed primarily to investigate the magnitude and time course of the effects of chronic oral doses (compared with a bolus iv dose) of tacrine on succinylcholine at the fast-twitch tibialis cranialis and slow-twitch soleus muscles in the rat. However, because tacrine potentiates evoked muscle twitch tension, ${ }^{7}$ which might influence the interaction of tacrine with succinylcholine, the twitch-augmenting effects of tacrine was also investigated.

\section{Methods}

\section{Animals}

Female adult Sprague Dawley rats (200-250 g initial weight) were used for this study which was approved by the Animal Care Sub-Committee of McGill University. The rats were randomly allocated to one of six groups that received tacrine, $2.5 \mathrm{mg} \cdot \mathrm{kg}^{-1}$ twice daily by gavage, for one (Chr 1), two (Chr 2), four (Chr 4 ) or eight (Chr 8) weeks, or $1 \mathrm{ml}$ saline twice daily by gavage for one to eight weeks (control), or an iv bolus dose of $2.5 \mathrm{mg} \cdot \mathrm{kg}^{-1}$ tacrine in the anaesthetized rat approximately $20 \mathrm{~min}$ before determining the dose-response curve of succinylcholine (acute). The study was designed with seven rats in each treatment group and 10 rats in the control group. However, as a result of death from anaesthesia, respiratory obstruction or bleeding, complete data were obtained from only five to six rats in each trearment group and eight rats in the control group.

\section{Protocol}

Twelve to $18 \mathrm{hr}$ after the last gavage of tacrine or saline, the rats were anaesthetized with $40 \mathrm{mg} \cdot \mathrm{kg}^{-1}$ pentobarbital sodium $i p$, and an endotracheal tube was inserted for mechanical ventilation with a Rodent Ventilator (Harvard Apparatus Ltd, South Natick, MA, USA) using air at $\sim 70$ breaths per minute and a tidal volume of $10 \mathrm{ml} \cdot \mathrm{kg}^{-1}(-3 \mathrm{ml})$ to maintain $\mathrm{PaCO}_{2}$ at $30-40 \mathrm{~mm} \mathrm{Hg}$. Lack of the withdrawal response to toe clamping was taken to indicate an adequate depth of anaesthesia which was maintained with intermittent doses of 3-5 mg pentobarbital $i p$. Rectal temperature was maintained at $37-38^{\circ} \mathrm{C}$ using a heating lamp. The jugular vein was cannulated for drug administration.

With the anaesthetized rat in lateral recumbency, one knee was rigidly stabilized in a clamp, the tibialis cranialis and soleus muscles were surgically exposed, the tendon of insertion of each muscle was attached to a Grass FT03 force displacement transducer (Grass Instruments Co, Quincy, MA, USA), and a tension of $50 \mathrm{~g}$ was applied to each muscle. The muscles were stimulated indirectly with electrical stimuli of $2 \mathrm{msec}$ duration and supramaximal intensity applied to the 
sciatic nerve at $2 \mathrm{~Hz}$ for $2 \mathrm{sec}$ every $12 \mathrm{sec}$ (train-offour pattern) using a Grass S88 stimulator and SIU5 stimulus isolation units. The evoked isometric twitch tension in both muscles was recorded simultaneously on a Grass polygraph (Model 7S1225). When the evoked twitch (baseline) had been stable for at least 10 min, cumulative doses of succinylcholine, in increments of $150 \mu \mathrm{g} \cdot \mathrm{kg}^{-1} i \mathrm{v}$, were given until the first twitch in the train-of-four (Tl) was depressed to $<5 \%$ of baseline in both muscles. An incremental dose was given only when the previous dose had produced its maximal effect as indicated by three equal consecutive $\mathrm{Tl}$ responses in both muscles or increasing $\mathrm{Tl}$ response in either muscle. The interval between doses averaged $60-90 \mathrm{sec}$. In the acute tacrine group, a bolus of $2.5 \mathrm{mg} \cdot \mathrm{kg}^{-1}$ tacrine $i v$ was given to the anaesthetized rat and the effects on evoked twitch tension were monitored until a new stable twitch tension was reached. Then, the cumulative dose-response curve of succinylcholine was determined as described above.

\section{Data collection and analysis}

The rats were weighed at weekly intervals and the mean body weight gain computed for each group. The effects of tacrine or saline administration on chewing, salivation, rearing, tremor, and muscle tone (as judged by body tone or rigidity during handling) were assessed subjectively. From the polygraph records the following parameters were obtained: (a) the maximum evoked twitch tension (i.e., maximum twitch augmentation) and the new stable evoked tension after $2.5 \mathrm{mg} \cdot \mathrm{kg}^{-1}$ tacrine $i v$; (b) the ratio of the fourth to the first twitch in the train-of-four twitches ( $\mathrm{T} 4 / \mathrm{Tl}$ ratio) in each muscle at maximum twitch augmentation and at the new stable twitch tension after $2.5 \mathrm{mg} \cdot \mathrm{kg}^{-1}$ tacrine $i v$; and (c) the $\mathrm{ED}_{50}$ and $\mathrm{ED}_{95}$ of succinylcholine (the dose of succinylcholine that depressed $\mathrm{Tl}$ to $50 \%$ and $5 \%$ of baseline, respectively) in each muscle for each experimental group derived from dose-response curves constructed by linear regression of the logit transformation of percentage depression of $\mathrm{Tl}$ versus the logarithm of the cumulative dose. Data were compared between experimental groups by one-way ANOVA and the Scheffé test, and between the tibialis and soleus muscles within groups by paired t test. $P \leq 0.05$ was considered statistically significant.

\section{Results}

\section{Effect of tacrine on behaviour and body weight}

Rats that received $2.5 \mathrm{mg} \cdot \mathrm{kg}^{-1}$ tacrine, twice daily by gavage, did not differ from control rats in grooming activity or muscle tone. Weight gain was also comparable in the treatment and control groups (Figure 2).

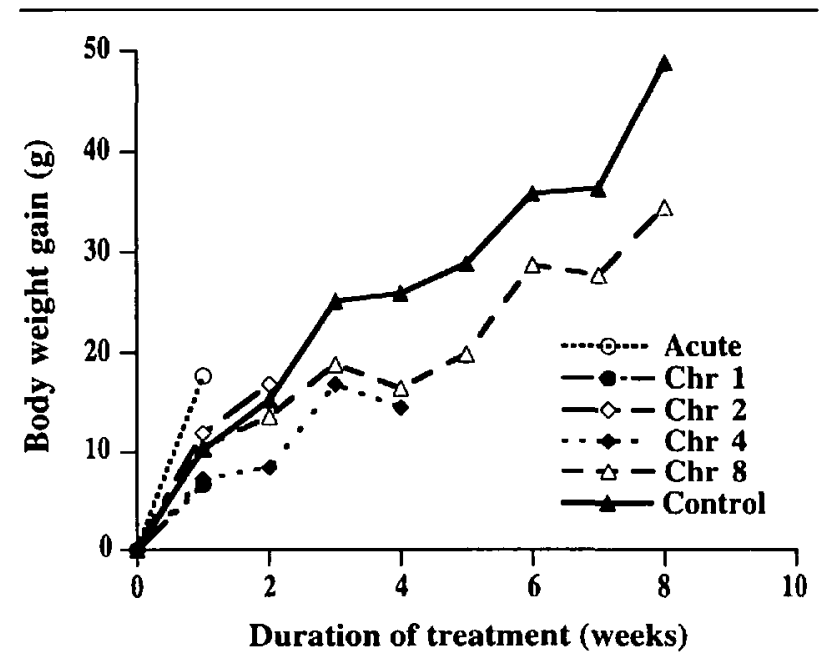

FIGURE 2 Mean weight gain in rats given $2.5 \mathrm{mg} \cdot \mathrm{kg}^{-1}$ tacrine twice daily by gavage for 1 (Chr 1), 2 (Chr 2), 4 (Chr 4) or 8 (Chr 8 ) $\mathrm{wk}$, or $1 \mathrm{ml}$ saline twice daily by gavage for $1-8 \mathrm{wk}$ (Control), or no treatment by gavage for $1 \mathrm{wk}$ (Acute). Error bars are omitted for clarity.

Effects of intravenous tacrine on twitch tension and train-of-four fade

Following $2.5 \mathrm{mg} \cdot \mathrm{kg}^{-1}$ tacrine $i v$, there was a transient increase in the evoked twitch tension to (mean \pm SD) $160 \pm 12 \%(P=0.0004)$ and $143 \pm 35 \%(P=0.0534)$ of baseline in the tibialis cranialis and soleus muscles, respectively. This was followed within 20 min by return to a new stable level $120 \pm 9 \%(P=0.007)$ and $123 \pm$ $20 \%(P=0.069)$ of baseline in the tibialis cranialis and soleus muscles, respectively (Figure $3 \mathrm{a}$ ).

Intravenous tacrine augmented evoked twitch tension. This effect was more marked on the first twitch, $\mathrm{Tl}$, than on the fourth twitch, $\mathrm{T} 4$, and thus resulted in train-of-four fade. In the tibialis muscle, the trainof-four ratio decreased from $0.95 \pm 0.04($ mean $\pm S D)$ before tacrine to $0.82 \pm 0.06(P=0.014)$ at maximum twitch augmentation and $0.83 \pm 0.07(P=0.013)$ after return of evoked twitch to a new stable level. Corresponding values in the soleus muscle were 1.02 $\pm 0.03,0.80 \pm 0.11(P=0.021)$ and $0.87 \pm 0.13(P=$ 0.106 ), respectively (Figure $3 \mathrm{~b}$ ).

\section{Effects of tacrine on the potency of succinylcholine}

The $\mathrm{ED}_{50}$ and $\mathrm{ED}_{95}$ of succinylcholine in the tibialis and soleus muscles of all groups are summarized in Table I. There were no differences in the $\mathrm{ED}_{50}$ or $\mathrm{ED}_{95}$ of succinylcholine between the acute or chronic tacrine groups and the control group. However, among the chronic tacrine groups, there was a tendency for the effective doses of succinylcholine in the tibialis muscle 

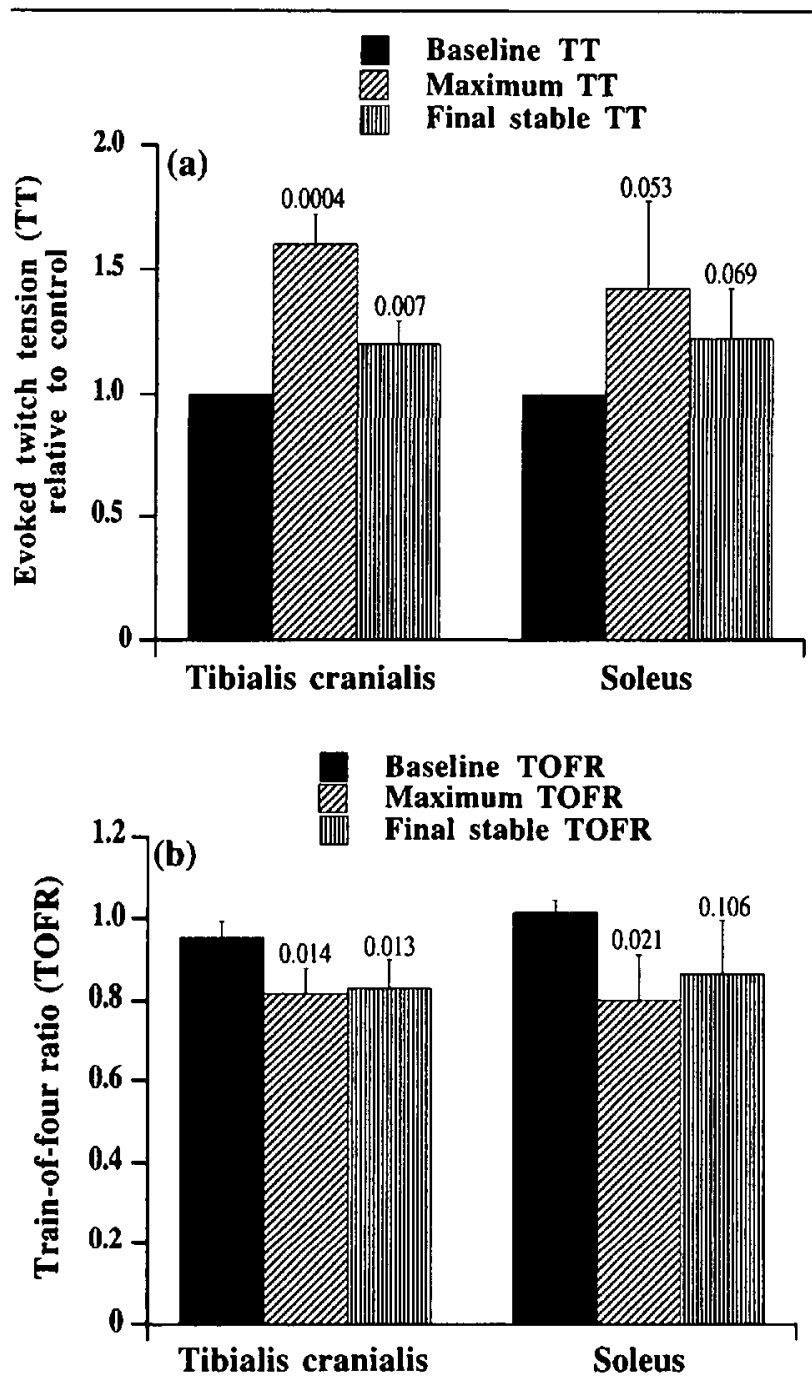

MUSCLE

FIGURE 3 The effects of acute tacrine, $2.5 \mathrm{mg} \cdot \mathrm{kg}^{-1}$, on (a) evoked twitch tension (normalized to baseline values) and (b) the train-of-four ratio in the tibialis and soleus muscles at baseline (i.e., before tacrine), maximum twitch augmentation and following return of evoked twitch to a new stable level after tacrine. $P$ values relative to baseline are indicated above each bar. (Error bars $=\mathrm{SD}$ ).

to decrease with duration of tacrine treatment, but this trend was not statistically significant. Within all (acute tacrine, chronic tacrine and control) groups, the tibialis muscle was more sensitive to succinylcholine than was the soleus muscle $(P<0.05$, paired $t$ test $)$.

\section{Discussion}

As an anticholinesterase, tacrine is expected to inhibit plasma cholinesterase activity and thus potentiate the actions of succinylcholine. Indeed, intravenous tacrine is known to potentiate succinylcholine blockade in the
TABLE I The mean $( \pm S D) E D_{50}$ and $\mathrm{ED}_{95}\left(\mu \mathrm{g} \cdot \mathrm{kg}^{-1}\right)$ of succinylcholine in the tibialis cranialis (TIB) and soleus (SOL) muscles in the six experimental groups

\begin{tabular}{lllll}
\hline Group & $T I B E D_{50}$ & $T I B E D_{95}$ & SOL ED & SOL $E D_{95}$ \\
\hline Control & $204 \pm 41$ & $382 \pm 96$ & $\mathbf{2 8 0} \pm 52$ & $629 \pm 168$ \\
Acute & $185 \pm 66$ & $390 \pm 161$ & $248 \pm 72$ & $588 \pm 133$ \\
Chr 1 & $197 \pm 24$ & $396 \pm 76$ & $333 \pm 64$ & $569 \pm 84$ \\
Chr 2 & $192 \pm 23$ & $376 \pm 41$ & $309 \pm 54$ & $665 \pm 281$ \\
Chr 4 & $166 \pm 23$ & $305 \pm 86$ & $258 \pm 21$ & $667 \pm 176$ \\
Chr 8 & $174 \pm 49$ & $277 \pm 80$ & $251 \pm 37$ & $546 \pm 148$ \\
F-test & 0.61 & 0.31 & 0.11 & 0.81 \\
\hline
\end{tabular}

cat and humans. ${ }^{7}$ Surprisingly, neither intravenous nor chronic oral tacrine altered the potency of succinylcholine in the rat in the present study. The reasons for these discrepancies are not clear but are probably related to species differences in the relative activities and substrate specificities of the various forms (pseudocholinesterase, aliesterases, arylesterases and erythrocyte cholinesterase) of cholinesterases in plasma. ${ }^{8,9}$ For example, plasma pseudocholinesterase activity is reported to be identical in female rats and cats and about $50 \%$ that in humans when measured at $\mathrm{pH} 8.4$ with the optimum substrate - propionylcholine for rats and butyrylcholine for cats and humans. Of the total esterase activity in plasma, $>95 \%$ is in the form of arylesterase and pseudocholinesterase in humans, acetylcholinesterase $(-75 \%)$ and aliesterase in the cat, and aliesterase $(-80 \%)$ and acetylcholinesterase in the rat. ${ }^{8,9}$ These differences might explain why there is no ideal animal species for toxicological studies of cholinesterase inhibition. ${ }^{9}$

Nonetheless, rats were used for this study because (a) the rat is the most popular model for predicting cholinesterase inhibition in humans; (b) the anticholinesterases, edrophonium, pyridostigmine and neostigmine have been demonstrated to prolong succinylcholine blockade in the rat; ${ }^{10}$ and (c) tacrine has been shown to inhibit cholinesterase activity at neuromuscular junctions in the rat as reflected by the antagonism of d-tubocurarine blockade and augmentation of evoked twitch tension. ${ }^{7,11}$ Hence, it was expected that any interactions between tacrine and succinylcholine should be demonstrable in the rat. The fast-twitch tibialis and slow-twitch soleus muscles were studied because they might differ in postsynaptic acetylcholinesterase activity, ${ }^{12}$ response (susceptibility to paralysis and tachyphylaxis) to succinylcholine, ${ }^{13}$ and sensitivity to the twitch-augmenting effects of tacrine, ${ }^{11}$ which might influence the interaction of tacrine with succinylcholine, with possible implications for monitoring neuromuscular 
blockade. Although the cumulative dose-response method might underestimate the potency of short-acting relaxant drugs such as succinylcholine, ${ }^{14}$ it was used in this study (a) to minimize the number of rats per group required to construct a dose-response curve, and (b) because the primary objective of the study was to compare the potency of succinylcholine among the groups rather than to estimate the effective doses of succinylcholine per se. Since the cumulative dose-response method was used in all groups, any errors inherent in the method should be identical across groups. Hence, the comparisons made between groups should be valid.

The present study confirms that acute tacrine augments evoked twitch tension while causing train-of-four fade in the rat. ${ }^{11}$ However, acute tacrine, did not potentiate succinylcholine blockade in the rat, contrary to findings in the cat and humans. ${ }^{7}$ This discrepancy cannot be explained by inadequate plasma concentrations of tacrine since the dose of tacrine given, $2.5 \mathrm{mg} \cdot \mathrm{kg}^{-1}$ $i v$, augmented evoked twitch tension and antagonized $d$-tubocurarine blockade in the rat. ${ }^{11}$ It may also not be related to the level of pseudocholinesterase activity in rat plasma since tacrine potentiates succinylcholine blockade in the $\mathrm{cat}^{7}$ which has similar levels of plasma pseudocholinesterase activity as female rats, ${ }^{9}$ and edrophonium, pyridostigmine and neostigmine potentiate succinylcholine blockade in the rat. ${ }^{10}$ Instead, it is tempting to speculate that the discrepancies in the interaction of acute tacrine with succinylcholine in rats compared with cats and humans may be related to differences in plasma aliesterase activities and, possibly, to differences in the substrate specificity of plasma pseudocholinesterase (butyrylcholine in cats and humans and propionylcholine in rats) among mammalian species. ${ }^{8,9}$ In this regard, it is noteworthy that plasma aliesterases are credited with binding and reducing plasma levels of free anticholinesterases thus reducing the levels that reach acetylcholinesterases in vital tissues such as the neuromuscular junction. ${ }^{9}$ Thus, the high levels of plasma aliesterases in rats might explain, at least partially, the failure of acute tacrine to alter the potency of succinylcholine in rats in the present study. The levels of plasma aliesterase activity in the rat probably also contributes to explain the lack of interaction between chronic oral tacrine and succinylcholine in this study. It might also explain why daily oral doses of $\sim 0.3-3$ $\mathrm{mg} \cdot \mathrm{kg}^{-1}$ tacrine, given in divided doses, produce adverse side effects, including hepatotoxicity, in some patients with $A D, 1-3,15$ whereas daily doses of tacrine as high as $40 \mathrm{mg} \cdot \mathrm{kg}^{-1}$ produced no clinical, gross or light microscopic signs of visceral organ pathology in rats and mice, ${ }^{16,17}$ both of which have high levels of plasma aliesterase activity. ${ }^{8,9}$
In the present study, there was a tendency for the $\mathrm{ED}_{95}$ of succinylcholine in the tibialis muscle to decrease with duration of tacrine treatment, but differences among the chronic tacrine groups were not significant. Although power analysis suggests that these differences would have been statistically significant had the sample size been 12 or more, the importance of and reasons for the progressive decline in $\mathrm{ED}_{95}$ with duration of tacrine treatment are not clear.

In conclusion, this study shows that, unlike in the cat and humans, ${ }^{7}$ acute tacrine does not potentiate succinylcholine blockade in the slow-twitch soleus or fast-twitch tibialis cranialis muscle in the rat. Consequently, the failure of chronic oral tacrine to alter the potency of succinylcholine in the rat may not be applicable to patients with $\mathrm{AD}$ on chronic tacrine therapy. Therefore, until the interactions between chronic oral tacrine and succinylcholine are determined in humans (since there may be no ideal animal models for such studies), there is need for increased vigilance in using succinylcholine or related drugs (e.g., mivacurium and remifentanil), that depend on plasma cholinesterase or other esterases for termination of their pharmacological action, in patients on chronic tacrine therapy.

\section{Acknowledgments}

We thank Burroughs Wellcome Inc., Canada, for partial funding of the study, Pharmascience Inc., Montreal, for generous supply of Tacrine, and Dr. J.A.J. Martyn for comments on the final version of the manuscript. C. Ibebunjo was supported by the Royal Victoria Hospital Research Institute and Fonds de la Recherche en Santé du Québec (FRSQ).

\section{References}

1 Summers WK, Majovski LV, Marsh GM, Tachiki K, Kling $A$. Oral tetrahydroaminoacridine in long-term treatment of senile dementia, Alzheimer type. N Engl J Med 1986; 315: 1241-5.

2 Farlow M, Gracon SI, Hershey LA, Lewis KW, Sadowsky CH, Dolan-Ureno J, for the Tacrine Study Group. A controlled trial of tacrine in Alzheimer's disease. JAMA 1992; 268: 2523-9.

3 Knapp MJ, Knopman DS, Solomon PR, Pendlebury WW, Davis CS, Gracon SI, for the Tacine Study Group. A 30-week randomized controlled trial of high-dose tacrine in patients with Alzheimer's disease. JAMA 1994; 271: 985-91.

4 Macdonald DJF. Dual block following tacrine and suxamethonium. Br J Anaesth 1967; 39: 629-32.

5 Chang CC, Chen TF, Chuang S-T. Influence of chronic neostigmine treatment on the number of acetylcholine 
receptors and the release of acetylcholine from the rat diaphragm. J Physiol (Lond) 1973; 230: 613-8.

6 Martyn JAJ, White DA, Gronert GA, Jaffe RS, Ward $J M$. Up-and-down regulation of skeletal muscle acetylcholine receptors. Effects on neuromuscular blockers. Anesthesiology 1992; 76: 822-43.

7 Karis JH, Nastuk WL, Katz RL. The action of tacrine on neuromuscular transmission: a comparison with hexafluoronium. Br J Anaesth 1966; 38: 762-74.

8 Wills $J H$. The measurement and significance of changes in the cholinesterase activities of erythrocytes and plasma in man and animals. Crit Rev Toxicol 1972; 1 : 153-202.

9 Ecobichon DJ, Comeau AM. Pseudocholinesterases of mammalian plasma: physicochemical properties and organophosphate inhibition in eleven species. Toxicol Appl Pharmacol 1973; 24: 92-100.

10 Valdrighi JB, Fleming NW, Smith BK, Baker GL, White $D A$. Effects of cholinesterase inhibitors on the neuromuscular blocking action of suxamethonium. $\mathrm{Br} \mathbf{~}$ Anaesth 1994; 72: 237-9.

11 Ibebunjo $C$, Donati $F$, Fox GS, Eshelby D, Tchervenkov $J I$. The effects of chronic tacrine therapy on $d$-tubocurarine blockade in the soleus and tibialis muscles of the rat. Anesth Analg 1997; 85: (in press).

12 Barnard EA, Rogers $A W$. Determination of the number, distribution, and some in situ properties of cholinesterase molecules in the motor end plate, using labeled inhibitor methods. Ann NY Acad Sci 1967; 144: 584-612.

13 Zaimis E, Head S. Depolarizing neuromuscular blocking drugs. In: Zaimis E (Ed.). Neuromuscular Junction. New York: Springer-Verlag, 1976; 365-419.

14 Smith CE, Donati F, Bevan DR. Dose-response curves for succinylcholine: single versus cumulative techniques. Anesthesiology 1988; 69: 338-42.

15 Watkins PB, Zimmerman HJ, Knapp MJ, Gracon SI, Lewis $K W$. Hepatotoxic effects of tacrine administration in patients with Alzheimer's disease. JAMA 1994; 271: 992-8.

16 Fitten LJ, Flood JF, Baxter CF, Tachiki KH, Perryman $K$. Long-term oral administration of memory-enhancing doses of tacrine in mice: a study of potential toxicity and side effects. J Gerontol 1987; 42: 681-5.

17 Flynn DD, Mash DC. Multiple in vitro interactions with and differential in vipo regulation of muscarinic receptor subtypes by tetrahydroaminoacridine. J Pharmacol Exp Ther 1989; 250: 573-81. 